\title{
The effects of COVID-19 on Airbnb
}

\author{
LAjos BOROS ${ }^{1}$, GÁbor DUd ÁS ${ }^{2}$ and TAMÁs KOVALCSIK ${ }^{1}$
}

\begin{abstract}
COVID-19 pandemic starting at the end of 2019, hit hard tourism and hospitality industries throughout the world. As a part of the processes, the most popular P2P accommodation service, the Airbnb also faced a rapid drop in bookings. This study explores and compares the effects of the first wave of the pandemic on the Airbnb markets of 15 cities. The analysis is based on the data retrieved from Insideairbnb.com. Booking trends are compared between 2019 and 2020 and a day-to-day analysis of occupancy rates during the first months of 2020 is also performed. Special attention was paid to the effects of pandemic on different price categories of listings. The results show that the evolution of local pandemic situation had the most significant impact on bookings and occupancy rates in the investigated cities. The characteristics of local markets and the pandemic and economic situation of sending countries had also great influence on the bookings and cancellations. In addition, in some cases the cancellations did not affect the reservations made for the later periods, meaning that tourists hoped for a quick recovery. The effect on price categories was also different from one location to another. The study provides empirical insights to the effects of the disease on P2P accommodations. Furthermore, the future of short-term rentals is also discussed briefly.
\end{abstract}

Keywords: Airbnb, tourism crisis, geography of pandemic, COVID-19, P2P accommodation, sharing economy

Received September 2020; Accepted November 2020.

\section{Introduction}

Infectious diseases have always posed threats for societies and economic activities (Jennings, L.C. et al. 2008; Strielkowski, W. 2020), but due to the increasing interconnectivity of our contemporary globalised world, diseases can spread even more rapidly to distant regions than before (Browne, A. et al. 2016; Semenza, J.C. and Ebi, K.L. 2019; Hall, C.M. et al. 2020; Wilson, M.E. and CHEN, L.H. 2020). Furthermore, information flows are also increasingly globalised, thus, people receive up-to-date reports on the spreading and consequences of the diseases or other disruptive events. Growing public awareness and perceived risk affects consumer decisions in tourism and hospitality industry (PAge, S. et al. 2012; Отоо, F.E. and Кім, S.S. 2018; HuAnG, D. et al. 2019; KIM, J. et al. 2020).
The COVID-19 (coronavirus) pandemic that appeared at the end of 2019 had a devastating effect on almost all aspects of social and economic life. Tourism, as a fragile and volatile sector (ÇAKAR, K. 2018) was no exception; as a matter of fact, it was among the most seriously affected sectors (Higgins-Desbiolles, F. 2020; UNWTO, 2020). Due to the closing down of borders, fear from the virus and the lockdown measures applied by local and national authorities (REN, X. 2020), international and domestic tourist flows decreased dramatically. Consequently, tourism sector experienced its largest downfall ever (Gössling, S. et al. 2020; STANKov, U. et al. 2020).

As a part of these processes, one of the most important online accommodation platforms, Airbnb was also hit hard by the pandemic. Airbnb guests cancelled their reservations or did not make new ones after the pandemic

\footnotetext{
${ }^{1}$ Department of Economic and Social Geography, University of Szeged, H-6722 Szeged, Egyetem u. 2. Hungary. E-mails: borosl@geo.u-szeged.hu (corresponding editor), kovalcsik.tamas@geo.u-szeged.hu

${ }^{2}$ Institute for Regional Studies, Centre for Economic and Regional Studies, Eötvös Loránd Research Network, H-5600 Békéscsaba, Szabó Dezső u. 42. Hungary. E-mail: dudasgabor5@gmail.com
} 
had started to spread (Dolnicar, S. and Zare, S. 2020). As a result, occupancy rates stagnated or decreased. The aim of this paper is to present the effects of the pandemic on the Airbnb markets, including the analysis of booking trends in 15 cities, the comparison of data from 2019 and 2020 and a more detailed analysis of occupancy rates in 2020. Furthermore, the effects on different price categories are also analysed in relation to each city.

\section{Literature review}

\section{Airbnb-characteristics and conflicts}

Several researches focus on the development and the conflicts of Airbnb in the last years. The key topics are the following: the motivations of guests, the strategies of hosts, characteristics of Airbnb supply and the effects of P2P accommodation on the destinations, regulatory aspects and taxation, the effects of Airbnb on tourism and hospitality sector and Airbnb itself as a company (DANN, D. et al. 2019; GutTENTAG, D. 2019). Several studies analyse the effects on housing markets, highlighting that due to the emergence of short-term rentals, entire apartments are withdrawn from local housing and rental markets leading to inflating rents and real estate prices (KE, Q. 2017; Robertson, D. et al. 2020). As a consequence, low-income residents are excluded from tourist areas, and those who remained also developed negative perceptions (Stergiou, D.P. and Farmaki, A. 2019). In relation to the above-mentioned processes, Airbnb is often related to gentrification (Dudás, G. et al. 2017; Wachsmuth, D. and Weisler, A. 2018; Robertson, D. et al. 2020). Several analyses emphasise that despite the "sharing" rhetoric, professional, business-like use is widespread: single hosts operate multiple listings (Boros, L. et al. 2018; Ferreri, M. and Sanyal, R. 2018. Adamiak, C. 2019; RobERTSON, D. et al. 2020). Airbnb can contribute to the transformation of city centres as well: since it can appear in already existing buildings, it intensifies crowding and tourism gentrification (Gutiérrez, J. et al. 2017).
The effects of Airbnb on traditional accommodation services is also often analysed: studies have found that Airbnb influences occupancy rates and hotel prices (Hong Choi, K. et al. 2015; Zervas, G. et al. 2017; Ginindza, S. and TichaAwa, T.M. 2019) or employment in tourism (FANG, B. et al. 2016). However, these effects are not uniform: the type of hotels (e.g. ownership) and location matter (Dogru, T. et al. 2020). Guttentag, G. (2015) described Airbnb as a disruptive innovation in the accommodation sector. Taxation, for example, is a key issue in this regard (Vinogradov, E. et al. 2020). Since the booking of accommodation happens through Airbnb, both guests and hosts tend to avoid taxes. This creates a competitive advantage for Airbnb as opposed to hotels. Furthermore, hotels must comply with the legal framework regarding the accommodation sector, while Airbnb listings are usually out of the scope of the regulations, which is also a competitive advantage for P2P accommodations (Boros, L. et al. 2018). In addition to the taxation issue, the regulatory aspect of P2P accommodations is also a widely discussed topic. Several studies highlighted that existing regulatory frameworks are not suitable for the management of Airbnb and its effects on the housing market or tourism sector (Edelman, B.G. and Geradin, D. 2015; Guttentag, G. 2017). Reacting to this problem, many cities introduced restrictive measures for Airbnb, e.g. maximizing the number of rental days, requiring the registration of hosts, or creating new administrative frameworks (HajıвABA, H. and DolnicAR, S. 2017).

The relation between P2P accommodation and traditional tourism services has a particular aspect in the post-socialist region, where tourism development is fragmented and not embedded in wider economic or urban development (GUNTER, U. and ÖNDER, I. 2018; KluUČNikov, A. et al. 2018; SмiтH, M. et al. 2018; Sмітн, M.K. et al. 2018; Belotti, S. 2019; Gyódi, K. 2019; RÁtz, T. et al. 2020). Due to the characteristics of post-socialist housing markets (e.g. ownership structures, processes of privatisation, regulatory frameworks) (see 
e.g. Enyedi, G. and Kovács, Z. 2006; Földi, Zs. 2006; SÝKora, L. and Bouzarovski, S. 2012; Grime, K. et al. 2019; Korcelli-OlejniczaK, E. and TAmmaru, T. 2020; Kovács, Z. 2020) the emergence of Airbnb contributed to the increase of socio-economic inequalities in post-socialist inner-cities. At the same time, the rise of Airbnb has also clearly contributed to the development of tourism in these cities, providing relatively cheap accommodation in city centres and nearby locations. According to recent research findings (e.g. Boros, L. et al. 2018; KLJUČNikov, A. et al. 2018) the share of multi-hosts (hosts managing more than one listing) in these cities is higher than the European average. At the same time, shortterm rentals are regulated moderately or not at all in post-socialist cities. Therefore, the effects of COVID-19 pandemic on the hospitality industry of post-socialist cities deserve special attention.

Previous research has also revealed that the most important motivations for using P2P accommodations are the lower costs compared to hotels and the value for price (GUTTENTAG, D. 2015; MAo, Z. and LyU, J. 2017; So, K.K.F. et al. 2018; PunG, J.M. et al. 2019), but other factors have their significance as well. TRAN, T.H. and Filimonau, V. (2020) identify four types of motivational factors: economic benefits, social benefits, functional attributes and experiences. On the other hand, lack of trust and perceived risk are both identified as de-motivational factors when considering listings on Airbnb (MAO, Z. and LyU, J. 2017; Mahadevan, R. 2018; MaO, Z.E. et al. 2020). At the same time, certain kinds and levels of risks can have a positive effect on consumer behaviour in $\mathrm{P} 2 \mathrm{P}$ accommodation services due to the perceived advantages (e.g. price, authenticity or location) and the risk-seeking attitude of travellers (ARUAN, D.T.H. and Felicia, F. 2019; Yi, J. et al. 2020). However, previous studies could only analyse the role of perceived risk on micro level: on the scale of host and guest and usually focused on certain markets. COVID-19 represents a more general and unprecedented risk. Since Airbnb is a major force shaping today's tour- ism and due to the magnitude of the local effects of P2P accommodations, it is important to understand how COVID-19 has affected local Airbnb markets. The future of Airbnb is related to the future of tourism and hospitality industry and the future of our cities.

\section{Diseases, risks and tourism and hospitality}

As it was mentioned in the Introduction, tourism is a fragile sector, often severely affected by crises, natural or human-made disasters or disease outbreaks (ÇAKAR, K. 2018; REDDY, M.V. et al. 2020). Thus, the consequences of these unfavourable events and post-crisis management aspects are often on the agenda. In the last two decades several major disruptions have affected international tourism, such as terrorist attacks (e.g. in New York, 2001; in Bali, 2002), the global economic crisis in 2008-2009, the eruption of the volcano Eyjafjallajokull in 2010 or the 2004 tsunami in South Asia (HALl, C.M. 2010; LiM, J. and Won, D. 2020). The most important disease outbreaks that had effects on tourism and hospitality industry were the bovine spongiform encephalopathy ("mad cow disease") in 2002-2003, the Severe Acute Respiratory Syndrome (SARS-CoV) in 2003, the avian flu in 2004, swine flu in 2009 (H1N1), Middle East respiratory syndrome-related coronavirus in 2012 (MERS-CoV) and the Ebola outbreak in 2014. All of them have been analysed and discussed intensely in the academic literature, focusing on the effects of the diseases, presenting post-crisis management perspectives and highlighting the importance of precaution (Sharpley, R. and Craven, B. 2001; Baxter, E. and Bowen, D. 2004; Henderson, J.C. and NG, A. 2004; Gu, H. and Wall, G. 2006; McAleer, M. et al. 2010; Wu, E.H.C. et al. 2010; RAssY, D. and SмiтH, R.D. 2013). However, despite the calls for proactive crisis management, most of the national governments failed to elaborate effective plans for disease-related tourism management and communication (JAMAL, T. and BudKe, C. 2020). 
Many authors concluded that the outbreaks usually caused decline in tourist arrivals, due the fact that tourists were concerned about their health and safety (Kuo, H.-I. et al. 2009; MaO, C.-K. et al. 2010; LeE, C.-K. et al. 2012; Joo, H. et al. 2019) and to non-pharmaceutical interventions (such as surveillance, border control and quarantine) (LEE, C.-K. et al. 2012; Ho, L.-L. et al. 2017; Ryu, S. et al. 2020). However, the effects can vary depending on the type of tourism (SHI, W. and LI, K.X. 2017). Furthermore, it is also important to point out that tourism is not only affected by diseases but is also connected with their spread. The greater mobility of people and the accessibility and affordability of air travel contribute to the rapid spread of infectious diseases (Davis, X.M. et al. 2013; OMrani, A.S. and Shalhoub, S. 2015; Findlater, A. and Bogoch, I.I. 2018).

As previous works on crises and tourism demonstrated, the perception of risk has a significant role in tourist decisions (Reisinger, Y. and Mavondo, F. 2005; Law, R. 2006; TANG, C.F. and TAN, E.C. 2016; Novelli, M. et al. 2018), although the awareness of individuals varies depending on their experiences and knowledge (WIDMAR, N.J.O. et al. 2017; Nelson, E.J. et al. 2019). If travellers are concerned about their health and safety, it affects tourist flows negatively. Several studies confirmed that negative effects tend to appear quickly, while the recovery could take longer time (LeAn, H. and SMyth, R. 2009). Lim, J. and Won, D. (2020) investigated the recovery of tourism in Taiwan after the outbreak of SARS. Their research showed that the tourist arrivals from different markets recovered at a different rate, because the risks were perceived differently among travellers from Hong Kong, the United States or Japan. The perceptions were affected by local experiences regarding the virus or the trust in health organisations. Consequently, in the case of Japan recovery of tourist flows took longer.

Since travel decisions are strongly related to perceptions of risks, the role of communication is crucial in shaping fear and concern among potential consumers - as it was highlighted by several case studies (e.g. FAulKner, B. 2001; Baxter, E. and Bowen, D. 2004; Kuo, H.-I. et al. 2009; Sparke, M. and Anguelov, D. 2012; Fisher, J.J. et al. 2018; Maphanga, P.M. and Henama, U.S. 2019; Jamal, T. and Budke, C. 2020). Disease outbreaks influence consumer behaviour negatively - even if a virus does not infect humans (such as the case of avian flu demonstrates - KIM, J. et al. 2020). Alarmist voices in media strengthen the perception of risk, causing panic and leading to more severe consequences in tourism (Monterrubio, J.C. 2010), affecting destination image (Hugo, N. and Miller, H. 2017).

Communication is also important during the recovery: destinations and hotels have to convey messages about safety - focusing on revenue-generating markets. National tourism agencies play a crucial role in coordinating and supporting these activities - see the example of Tourism Authority of Thailand after the 2004 tsunami. In addition to the marketing efforts, price has also a significant role during recovery: hotels can offer discounts or special packages to attract guests (Henderson, J.C. 2005). On the other hand, cost reduction (e.g. lower labour costs, stricter financial control, reduced level of services etc.) is also an often used strategy (CAmpiranon, K. and ScotT, N. 2014). Collaboration between various actors of tourism (e.g. between hotels, airlines, travel agencies etc.) may also contribute to cost reduction through the economies of scale, help the formation of shared visions of future, increase the influence of stakeholders on future policies, and strengthen the relations between actors (HowEs, M. et al. 2015; JiAnG, Y. and Ritchie, B.W. 2017). So far, the effects of diseases on Airbnb have been rarely analysed, due to the fact that since the emergence of this accommodation platform, there have been only a few disease outbreaks that affected tourism markets, and only with limited effect. According to Hu, M.R. and LEE, A.D. (2020) the lockdown in Wuhan, the local appearance of COVID-19 and the introduction of local restrictions all had negative 
effects on Airbnb bookings - but the importance of these factors varied from one region to another. The geographical distance of disease hotspots and the local mobility levels also influenced the number of cancellations. As their analysis on London shows, the pandemic affected the structure of demand as well: due to the lower level of host-guest contact, entire homes had a competitive advantage against private rooms. Although COVID-19 pandemic caused severe crisis in tourism industry, reducing spending power and tourist demand, the first negative effects of the disease outbreak were mainly caused by the perceived risks (RIverA, M.A. 2020). This is mainly because economic problems started later than the reports on the disease outbreak had started to dominate public and political discourses.

Based on the above-mentioned risk and pandemic related context, the main questions of this research are the following: How has the pandemic hit the analysed cities; what were the main differences among them? Which factors did influence the magnitude of the decrease in bookings and cancellations the most? How were different price categories affected by the pandemic?

\section{COVID-19: characteristics of the disease and a brief timeline of the pandemic}

The first confirmed case of COVID-19 was reported in Wuhan, China on 1 December 2019 - although according to several reports there had been earlier cases of the disease. The new disease (as pneumonia of unknown cause) was reported on 31 December 2019 to the World Health Organization (WHO) Country Office in China. Several researches reported that the coronavirus appeared in Europe in the last quarter of 2019, however, the public was not aware of the danger at that time. The impact of the disease started to manifest in tourism when the disease had become a global pandemic and various non-pharmaceutical interventions were applied by national governments or global organisations (travel bans, border closures, state of emergency etc.). As a result of these measures, the threat posed by coronavirus became more evident for travellers, thus, it had a larger role in their decisions.

The name COVID-19 for the disease was announced on 11 February 2020. The WHO declared the outbreak as public health emergency of global concern on 30 January 2020. It was the sixth time that an emergency of this scale had been identified (Kamel Boulos, M.N. and Geraghty, E.M. 2020; Zheng, Y. et al. 2020). On 11 March 2020, the outbreak was classified as pandemic by the WHO (2020). The virus rapidly spread outside China during January (according to the epidemiological reports); the first infected person outside China was reported in Thailand on 13 January, while the first European case was reported in France on 24 January (Worldometer, 2020). The first COVID-19 related deaths in the countries concerned in our research were reported during February. National governments reacted by introducing travel restrictions and declaring states of emergency although the timing and the exact nature of measures varied. For example, Brazil did not declare a national state of emergency, only certain cities did so. On the other hand, most of the European countries announced state of emergency almost at the same time - in the middle of March. These actions were coincided with or were followed by travel restrictions and borders closures - to slow down or prevent the spread of the disease (Figure 1).

\section{Data and methods}

The data used in this analysis was retrieved from the database of insideairbnb.com (Insideairbnb, 2020). This webpage provides free data on offers and bookings of local Airbnb markets. The dataset contains information on the actual price (on the day of the data collection) and availability (stored in a Boolean variable: true-false) of all listings for the next 12 months. The data is updated monthly, thus, can be used for longitudinal 


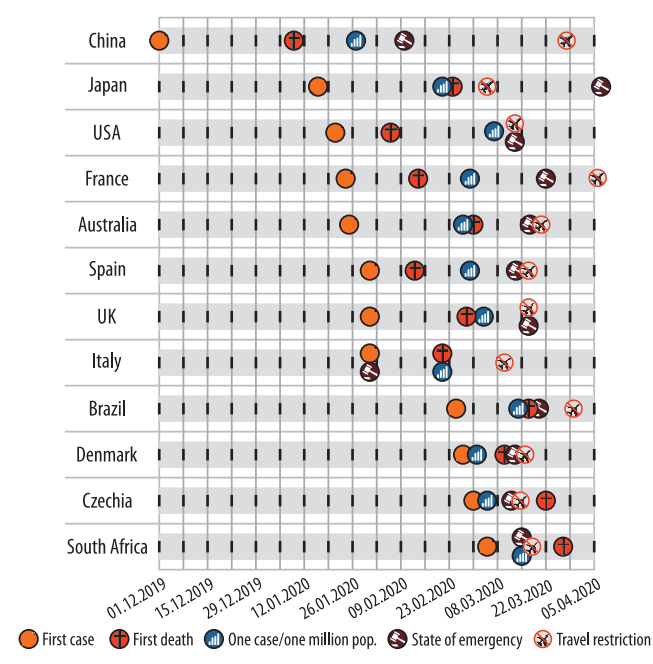

Fig. 1. The timeline of the spread of COVID-19 and measures and restrictions taken by different countries. Source: Edited by the authors.

analyses; analysing booking trends, prices and comparing them between various cities. The dataset has its limitations though: it does not contain data from all Airbnb listings worldwide, but only for selected cities. Furthermore, the timeframe of the data available in different locations can differ; in some cases (e.g. Tokyo), the earliest available data is from the middle of 2019, thus, it is not always possible to make a year-to-year comparison between the data from 2019 and 2020. Furthermore, the data collections in various cities do not cover exactly the same time periods (Table 1).

Last but not least, although the dataset contains availability and price data for each and all listings for the next 365 days, a large part of those listings becomes unavailable after three months (i.e. the value of the availability variable is 'false' for all days from the $4^{\text {th }}$ month to the $\left.12^{\text {th }}\right)$. Our assumption is that most of them are not withdrawn from the market but are usually offered only for the next three months. As a result, a significant share of local Airbnb markets is not represented in the data for the above-mentioned period. Thus, the analysis is always based on the data for a three months' period starting from the day of the data collection (i.e. in our analysis the overlap between consecutive data collections is two months - due to the reliability of data, only these months can be compared).

To answer our research questions, we have analysed the changes in booking rates in 15 cities (London, New York, Paris, Sydney, Los Angeles, Beijing, Rio de Janeiro, Copenhagen, Rome, Cape Town, Madrid, Barcelona, Prague, Tokyo and Milan). The choice of cities was based on their tourism importance within Airbnb and because the aim was to represent various parts of the world and to provide a more comprehensive analysis of the early effects of coronavirus. Thus, the 9 largest local Airbnb markets (based on the number of listings) were selected. Madrid, Barcelona and Milan were added to the analysis because of the severity of the pandemic in these cities. Furthermore, in order to provide a more comprehensive overview, the trends of Cape Town (the largest African market) and Prague (the largest post-socialist market) were also analysed. In addition, the selection of Prague was also motivated by the fact that most of the post-socialist countries had lower infection ratio compared to Western Europe (KouǩIL, P. and Ferenčunoví, S. 2020). Due to the limitations of data availability various cities had to be excluded from the analysis or could only partly be analysed. In addition, since the pandemic hit Asian countries first, the timeframe of the data collection is different in the casestudy cities. In the cases of Tokyo and Beijing data from November to February were used, while in other cases the timeframe was from December to March (Table 2).

During our research, we used the data on availability and prices to analyse the changes in booking rates and to compare cancellations and new bookings among various price categories (price quartiles) for all cities. Four datasets were analysed in all cases: every month from December 2019 to March 2020. This timeframe covers the time when the world was not yet aware of the dangers of COVID-19 and the time when the virus 
Table 1. Dates of the data collections

\begin{tabular}{|c|c|c|c|c|c|}
\hline City & Year & $\begin{array}{c}\text { Date-1 } \\
\text { P-I }^{*}\end{array}$ & $\begin{array}{c}\text { Date-2 } \\
\text { P-I - P-II** }\end{array}$ & $\begin{array}{c}\text { Date-3 } \\
\text { P-II - P-III }\end{array}$ & $\begin{array}{c}\text { Date-4 } \\
\text { P-III**** }\end{array}$ \\
\hline Barcelona & $\begin{array}{l}2019 \\
2020 \\
\end{array}$ & $\begin{array}{l}10.12 .2018 \\
10.12 .2019\end{array}$ & $\begin{array}{l}14.01 .2019 \\
10.01 .2020\end{array}$ & $\begin{array}{l}06.02 .2019 \\
16.02 .2020\end{array}$ & $\begin{array}{l}08.03 .2019 \\
16.03 .2020\end{array}$ \\
\hline Madrid & $\begin{array}{l}2019 \\
2020 \\
\end{array}$ & $\begin{array}{l}10.12 .2018 \\
10.12 .2019\end{array}$ & $\begin{array}{l}14.01 .2019 \\
10.01 .2020\end{array}$ & $\begin{array}{l}06.02 .2019 \\
18.02 .2020\end{array}$ & $\begin{array}{l}08.03 .2019 \\
17.03 .2020 \\
\end{array}$ \\
\hline Rio de Janeiro & $\begin{array}{l}2019 \\
2020 \\
\end{array}$ & $\begin{array}{l}14.12 .2018 \\
23.12 .2019\end{array}$ & $\begin{array}{l}18.01 .2019 \\
21.01 .2020\end{array}$ & $\begin{array}{l}11.02 .2019 \\
25.02 .2020\end{array}$ & $\begin{array}{l}13.03 .2019 \\
18.03 .2020 \\
\end{array}$ \\
\hline London & $\begin{array}{l}2019 \\
2020 \\
\end{array}$ & $\begin{array}{l}07.12 .2018 \\
09.12 .2019 \\
\end{array}$ & $\begin{array}{l}13.01 .2019 \\
09.01 .2020 \\
\end{array}$ & $\begin{array}{l}05.02 .2019 \\
16.02 .2020\end{array}$ & $\begin{array}{l}07.03 .2019 \\
15.03 .2020\end{array}$ \\
\hline New York & $\begin{array}{l}2019 \\
2020 \\
\end{array}$ & $\begin{array}{l}06.12 .2018 \\
04.12 .2019\end{array}$ & $\begin{array}{l}09.01 .2019 \\
03.01 .2020\end{array}$ & $\begin{array}{l}01.02 .2019 \\
12.02 .2020\end{array}$ & $\begin{array}{l}06.03 .2019 \\
13.03 .2020\end{array}$ \\
\hline Paris & $\begin{array}{l}2019 \\
2020\end{array}$ & $\begin{array}{l}07.12 .2018 \\
10.12 .2019\end{array}$ & $\begin{array}{l}13.01 .2019 \\
09.01 .2020\end{array}$ & $\begin{array}{l}05.02 .2019 \\
16.02 .2020\end{array}$ & $\begin{array}{l}11.03 .2019 \\
15.03 .2020\end{array}$ \\
\hline Sydney & $\begin{array}{l}2019 \\
2020 \\
\end{array}$ & $\begin{array}{l}07.12 .2018 \\
08.12 .2019 \\
\end{array}$ & $\begin{array}{l}13.01 .2019 \\
07.01 .2020 \\
\end{array}$ & $\begin{array}{l}04.02 .2019 \\
15.02 .2020\end{array}$ & $\begin{array}{l}07.03 .2019 \\
16.03 .2020 \\
\end{array}$ \\
\hline Los Angeles & $\begin{array}{l}2019 \\
2020 \\
\end{array}$ & $\begin{array}{l}06.12 .2018 \\
05.12 .2019\end{array}$ & $\begin{array}{l}11.01 .2019 \\
04.01 .2020\end{array}$ & $\begin{array}{l}03.02 .2019 \\
13.02 .2020\end{array}$ & $\begin{array}{l}06.03 .2019 \\
03.03 .2020\end{array}$ \\
\hline Beijing & $\begin{array}{l}2019 \\
2020 \\
\end{array}$ & $\begin{array}{l}15.11 .2018 \\
24.11 .2019\end{array}$ & $\begin{array}{l}14.12 .2018 \\
26.12 .2019\end{array}$ & $\begin{array}{l}18.01 .2019 \\
21.01 .2020 \\
\end{array}$ & $\begin{array}{l}11.02 .2019 \\
26.02 .2020\end{array}$ \\
\hline Rome & $\begin{array}{l}2019 \\
2020 \\
\end{array}$ & $\begin{array}{l}11.12 .2018 \\
12.12 .2019\end{array}$ & $\begin{array}{l}16.01 .2019 \\
12.01 .2020 \\
\end{array}$ & $\begin{array}{l}07.02 .2019 \\
19.02 .2020 \\
\end{array}$ & $\begin{array}{l}08.03 .2019 \\
30.03 .2020 \\
\end{array}$ \\
\hline Milan & $\begin{array}{l}2019 \\
2020 \\
\end{array}$ & $\begin{array}{l}11.12 .2018 \\
11.12 .2019 \\
\end{array}$ & $\begin{array}{l}16.01 .2019 \\
12.01 .2020 \\
\end{array}$ & $\begin{array}{l}07.02 .2019 \\
18.02 .2020\end{array}$ & $\begin{array}{l}08.03 .2019 \\
30.03 .2020\end{array}$ \\
\hline Copenhagen & $\begin{array}{l}2019 \\
2020 \\
\end{array}$ & $\begin{array}{l}18.12 .2018 \\
31.12 .2019 \\
\end{array}$ & $\begin{array}{l}28.01 .2019 \\
29.01 .2020 \\
\end{array}$ & $\begin{array}{l}17.02 .2019 \\
28.02 .2020\end{array}$ & $\begin{array}{l}26.03 .2019 \\
22.03 .2020\end{array}$ \\
\hline Prague & $\begin{array}{l}2019 \\
2020 \\
\end{array}$ & $\begin{array}{l}21.12 .2018 \\
31.12 .2019 \\
\end{array}$ & $\begin{array}{l}29.01 .2019 \\
30.01 .2020 \\
\end{array}$ & $\begin{array}{l}18.02 .2019 \\
29.02 .2020\end{array}$ & $\begin{array}{l}28.03 .2019 \\
22.03 .2020 \\
\end{array}$ \\
\hline Cape Town & $\begin{array}{l}2019 \\
2020 \\
\end{array}$ & $\begin{array}{l}15.12 .2018 \\
28.12 .2019\end{array}$ & $\begin{array}{l}22.01 .2019 \\
26.01 .2020\end{array}$ & $\begin{array}{l}12.02 .2019 \\
27.02 .2020\end{array}$ & $\begin{array}{l}18.03 .2019 \\
21.03 .2020\end{array}$ \\
\hline Tokyo & 2020 & 28.11.2019 & 30.12.2019 & 28.01.2020 & 29.02 .2020 \\
\hline
\end{tabular}

*Beginning of the booking phase of the Period I. ${ }^{*}$ End of the booking phase of the Period I, and beginning of the booking phase of the Period II. ***End of the booking phase of the Period II, and beginning of the booking phase of the Period III. ${ }^{* * *}$ End of the booking phase of the Period III.

started to spread globally, severely affecting tourism flows and accommodation bookings. Since most of the travel restrictions were introduced during March, the analysed processes were influenced by the market trends without the governmental interventions. We compiled a timeline of the spreading of COVID-19 and national and local policy responses. According to several reports and analyses, the virus appeared earlier than the first confirmed cases indicate, but this is irrelevant for our analysis, the responses from governments, tourists or airlines were affected by the 'official' data and the measures tak- en by various actors within and outside the tourism sector (e.g. airlines, travel agencies).

Comparing of reservation numbers for the same days between two consecutive months, it is possible to determine change in occupancy rates of Airbnb listings. Growth is interpreted as net gain, while decrease is interpreted as net loss of reservations. If we have two data collections, one from 10 December 2019, the other from 10 January 2020 (i.e. booking phase), we can calculate and compare occupancy numbers for the days between 10 January and 10 March (i.e. travel phase). As we mentioned earlier, the 
Table 2. List of the case-study cities and justification of their selection

\begin{tabular}{c|l|c|c|l}
\hline \multirow{2}{*}{ Ranking } & \multirow{2}{*}{ City } & \multicolumn{2}{|c|}{ Number of } & \multirow{2}{*}{ Justification of selection } \\
\cline { 3 - 4 } & & listings & active listing & \\
\hline 1 & London & 87,571 & 58,261 & \\
2 & Paris & 66,414 & 35,097 & \\
3 & New York & 51,097 & 32,706 & \\
4 & Sydney & 40,434 & 22,821 & \multirow{2}{*}{ Top Airbnb market } \\
5 & Beijing & 39,732 & 35,393 & \\
6 & Los Angeles & 38,851 & 31,575 & \\
7 & Rio de Janeiro & 36,461 & 27,842 & \\
8 & Rome & 31,450 & 28,803 & \\
9 & Copenhagen & 28,418 & 10,997 & \\
\hline.. & & & & \\
\hline 13 & Cape Town & 24,591 & 20,357 & Top African Airbnb market \\
\hline.. & & & & \\
\hline 17 & Madrid & 21,845 & 17,899 & Severely hit by COVID-19 \\
\hline.. & & & & \\
\hline 19 & Barcelona & 20,981 & 18,210 & \multirow{2}{*}{ Severely hit by COVID-19 } \\
\hline 20 & Milan & 20,280 & 15,959 & \\
\hline.. & & & & Top Asian Airbnb market* \\
\hline 24 & Tokyo & 15,551 & 14,827 & Top post-socialist Airbnb market \\
\hline 25 & Prague & 14,560 & 11,631 & \\
\hline
\end{tabular}

*Outside of China. Source: Edited by the authors based on data from InsideAirbnb, 2020.

reliability of data drops significantly after the third month of the travel phases. As the first step of the analysis, a year-to-year comparison of bookings was made to understand the dynamics of local Airbnb markets. In the next phase of research, in order to gain a more detailed understanding of the temporal changes, a day-to-day comparison of booking numbers was made; and changes in the number of bookings for each day of the travel phase were calculated. Finally, to understand how various price categories were affected by the pandemic, the changes of bookings in the price quartiles of cities were compared.

\section{Results}

As the first step of the analysis, the changes in the number of bookings between 2019 and 2020 were compared. Figure 2 shows the average net gain/loss in reservations per day for each travel phase. These numbers were calculated by dividing the total number of new reservations made during the preceding booking phase by the number of days within the travel phase. Each period shown in Figure 2 consists of a booking and a travel phase (see Table 1).

Compared to the previous year, all the analysed cities show a decrease in the number of new bookings between February and March 2020 - the largest one was experienced in Rome. Although the most affected region was Lombardy (ca. $600 \mathrm{~km}$ from Rome), the decrease in Milan was lower. Paris and Prague also suffered significant drops. Spain was hit severely by COVID-19 which is reflected in the number of bookings as well: the number of cancellations exceeds the number of new bookings for Barcelona and Madrid in the third period of 2020, when the pandemic situation started to evolve in the country. It means that the number of bookings from March to May dropped significantly.

In the first half of February, Airbnb bookings in Beijing were suspended until May (Reuters, 2020), thus, the last analysed pe- 

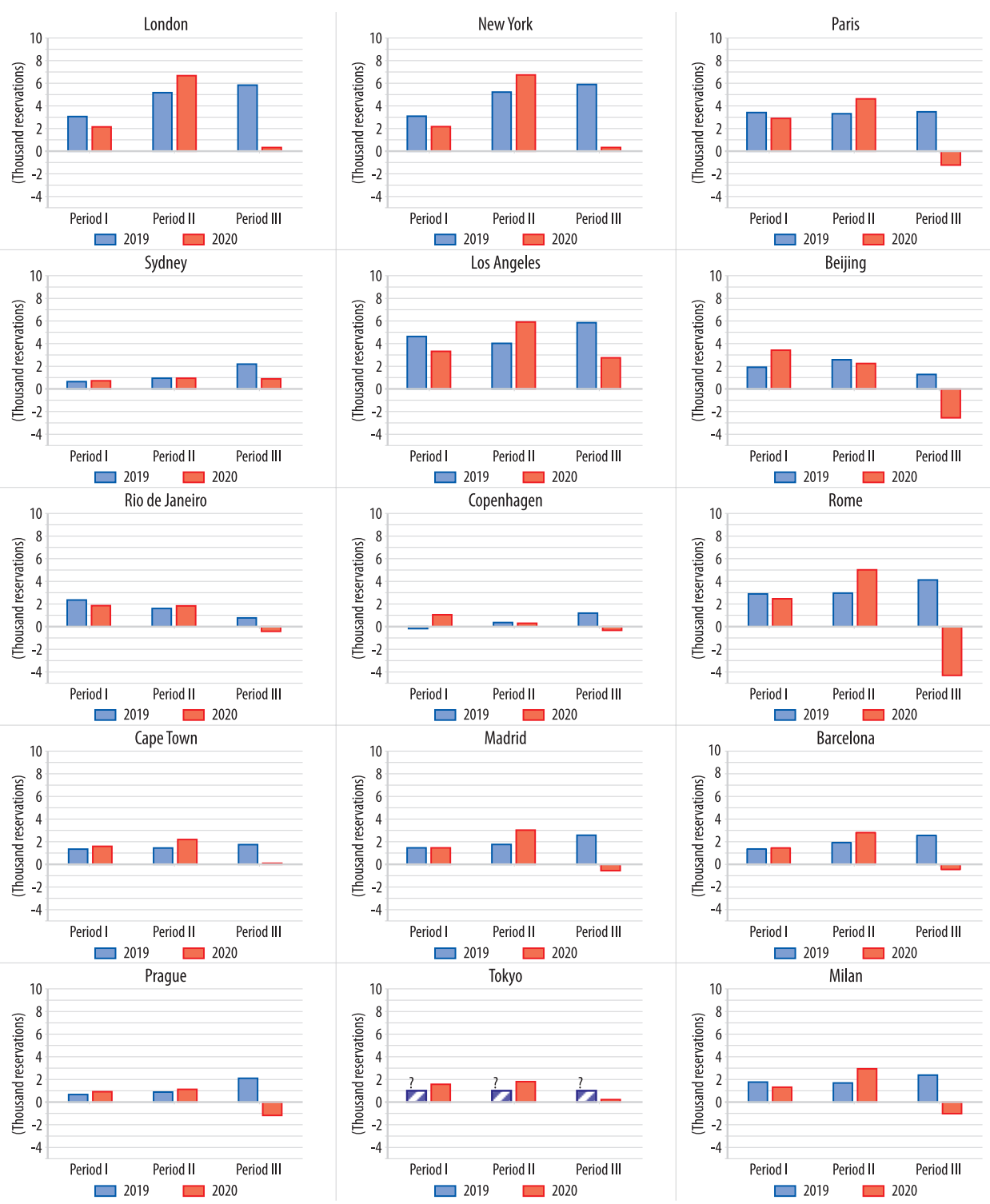

Fig. 2. Changes in daily average reservations, comparison of 2019 and 2020. Source: Edited by the authors.

riod from 2020 shows the largest drop in the number of bookings - but this is due to administrative reasons. The processes in London and New York are quite similar the reason could be that as global cities they are both deeply embedded into global flows of people and information. In Los Angeles, the number of bookings decreased, but the number of new bookings in Period III almost matched the level of Period I. Additionally, Los Angeles showed the largest number of new bookings in Period III. Although the first confirmed cases in the United States were reported in January, Los Angeles remained 
slightly affected until the middle of March. Our assumption is that in this case, traveller choices were affected mostly by the local situation, and the spreading of virus in other states had a lower significance. The restrictions for travellers from the Schengen Zone were introduced on 13 March, and so they did not affect the booking trends analysed in this research.

Since December, January and February are summer months on the Southern Hemisphere, the peak tourism season falls to this period. Christmas season also strengthens tourism in this period so the significance of "last minute" bookings is lower in Sydney, Rio de Janeiro and Cape Town than in the other investigated cities - i.e. travellers book their accommodations well before the travel date. Thus, the number of new reservations and the decrease in the third period are also lower in the cities of the Southern Hemisphere. In addition, the pandemic has appeared later in Cape Town and Rio de Janeiro compared to the other analysed cities. The year-to-year comparison was not possible in the case of Tokyo due to the missing data for 2019 - but compared to the first two periods in 2020 there were almost no new reservations in the third.

When analysing the effects of various events and milestones on Figure 1, the results show that the global events (e.g. declaration of public health emergency of global concern) had little effect on booking and cancellation trends. Instead, the local pandemic situation had more significant role in these processes; the change in the number of bookings correlates with the time elapsed from the date when the rate of fatalities exceeded the one person/million value. With time the drop in booking numbers was larger. There were two exceptions: Rio de Janeiro and Sydney. In both cases, local conditions and processes may explain this deviation. In Rio de Janeiro, the low level of COVID-19 testings and political attitudes towards the disease decreased the official numbers of infections and fatalities. While Australian bookings might have been affected by extensive wildfires.
It is important to note that other factors than COVID-19 also had their impacts on tourism and Airbnb reservations. The possible effects of Australian wildfires were already mentioned. In addition, China is the most important source of international visitors in Australia; the evolving pandemic situation in China could also affect the number of reservations. This was particularly the case after Australia had introduced a travel ban for visitors from China on 1 February 2020 (Champer Champ, 2020).

In the second step of the research, the aim was to provide a more detailed picture of the processes presented above. Thus, a day-to-day analysis was made for the occupancy rates for four data collection dates. The lines on Figure 3 show the percentage of booked listing at the time when these data collections were made for each consecutive day. The areas between lines present direction and the extent within the change. If the lines representing a later data collection time decreases below the one representing the earlier data, then a net loss in occupancy is experienced. As we mentioned earlier, Airbnb bookings were suspended in Beijing in the first half of February 2020.

The graphs on Figure 3 confirm the abovementioned statements - but they also reveal some peculiarities. The differing trend lines highlight the differences in booking strategies. For example, in the case of Rio de Janeiro, the steepness of the trend lines shows that most bookings are made just before the travel. In the cases of Madrid and Barcelona a net loss in occupancy can be seen from the middle of March. At the same time, this negative trend seems to have a lower effect towards the end of Period III; travellers booked accommodation for May during the third booking phase (the beginning of March). It shows that some tourists trusted that the pandemic situation would disappear by May - confirming the role of risk perception in travel plans. In Rome the bookings disappeared for the whole Period III - showing a different perception of risk in that case. In Paris and Prague, the cancellation ratio was high, but similarly to Madrid and Barcelona guests did not cancel their bookings for the end of April. 

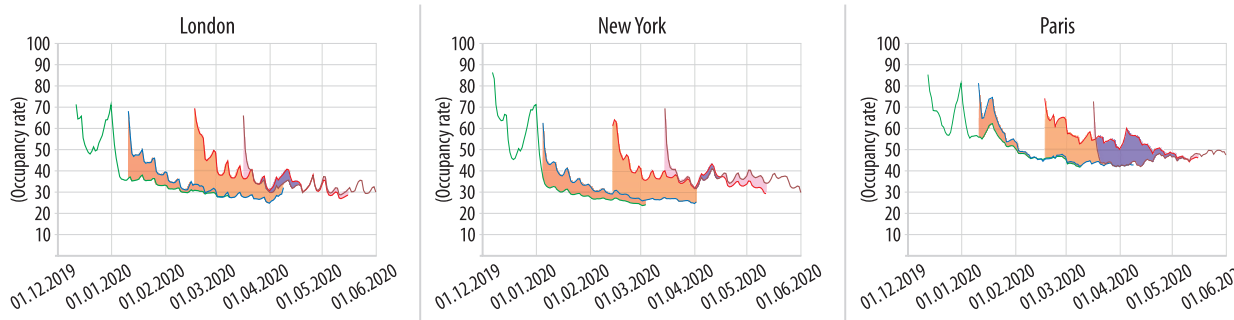

$-09.12 .2019\left(t_{1}\right)-09.01 .2020\left(t_{2}\right)-16.02 .2020\left(t_{3}\right)-15.03 .2020\left(t_{t}\right)$

$-09.12 .2019\left(t_{1}\right)-09.01 .2020\left(t_{2}\right)-16.02 .2020\left(t_{3}\right)-15.03 .2020\left(t_{3}\right)$

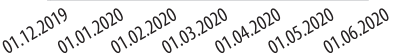
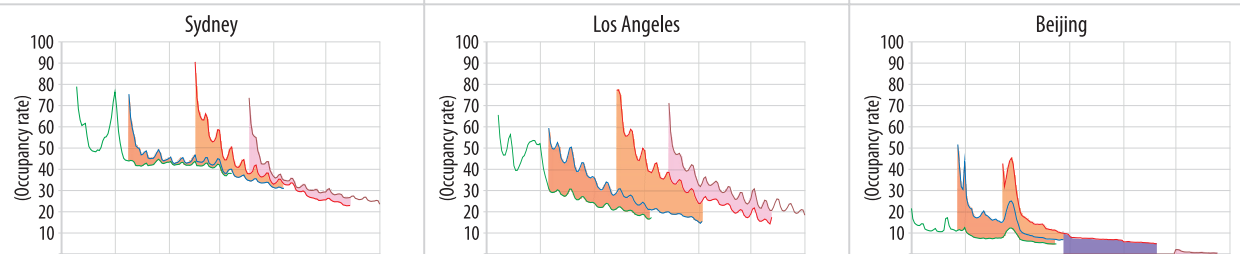

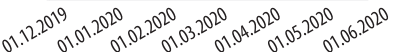

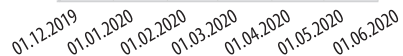

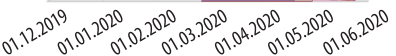

$-09.12 .2019\left(\mathrm{t}_{1}\right)-09.01 .2020\left(\mathrm{t}_{2}\right)-16.02 .2020\left(\mathrm{t}_{3}\right)-15.03 .2020\left(\mathrm{t}_{4}\right)-09.12 .2019\left(\mathrm{t}_{1}\right)-09.01 .2020\left(\mathrm{t}_{2}\right)-16.02 .2020\left(\mathrm{t}_{3}\right)-15.03 .2020\left(\mathrm{t}_{4}\right)-$
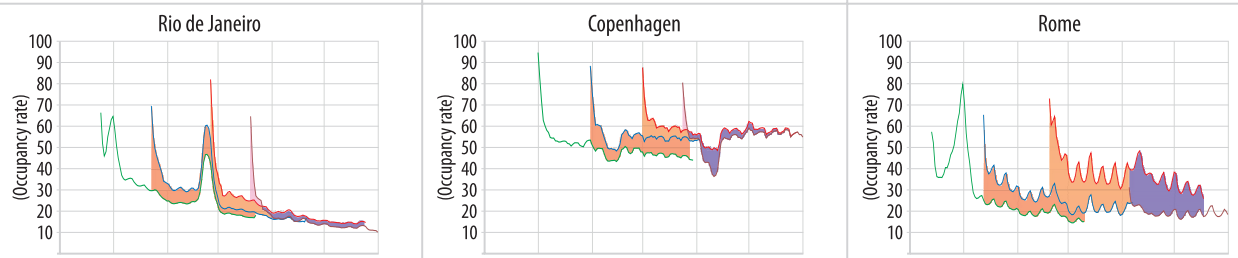

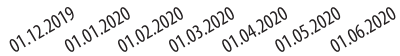

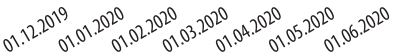

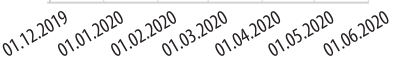

$-09.12 .2019\left(t_{1}\right)-09.01 .2020\left(t_{2}\right)-16.02 .2020\left(t_{3}\right)-15.03 .2020\left(t_{4}\right)$

$09.12 .2019\left(\mathrm{t}_{7}\right)-09.01 .2020\left(\mathrm{t}_{2}\right)-16.02 .2020\left(\mathrm{t}_{3}\right)-15.03 .2020\left(\mathrm{t}_{4}\right)$

$-09.12 .2019\left(\mathrm{t}_{1}\right)-09.01 .2020\left(\mathrm{t}_{2}\right)-16.02 .2020\left(\mathrm{t}_{3}\right)-15.03 .2020\left(\mathrm{t}_{4}\right)$
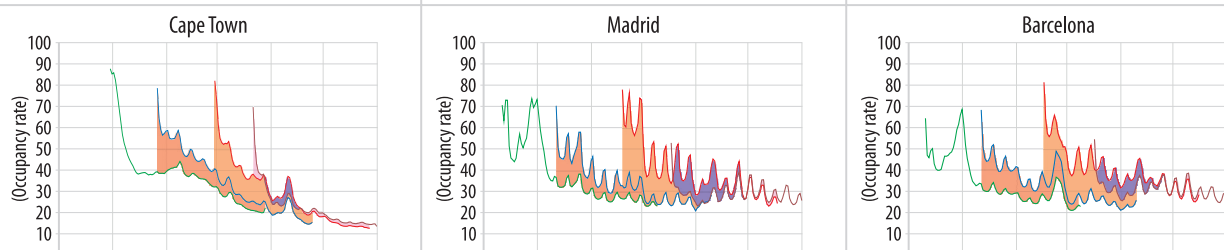

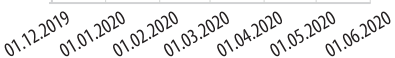

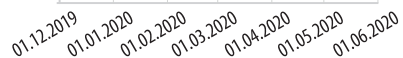

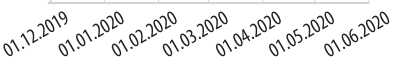

$-09.12 .2019\left(\mathrm{t}_{1}\right)-09.01 .2020\left(\mathrm{t}_{2}\right)-16.02 .2020\left(\mathrm{t}_{3}\right)-15.03 .2020\left(\mathrm{t}_{4}\right)-09.12 .2019\left(\mathrm{t}_{1}\right)-09.01 .2020\left(\mathrm{t}_{2}\right)-16.02 .2020\left(\mathrm{t}_{3}\right)-15.03 .2020\left(\mathrm{t}_{4}\right)-$

$-09.12 .2019\left(t_{1}\right)-09.01 .2020\left(t_{2}\right)-16.02 .2020\left(t_{3}\right)-15.03 .2020\left(t_{4}\right)$
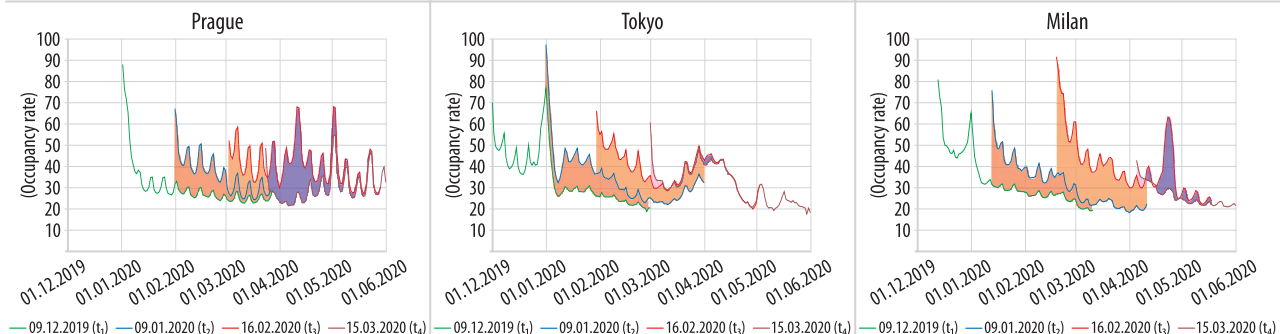

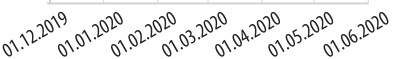

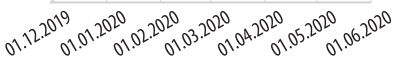

\begin{tabular}{cccc}
$-09.12 .2019\left(\mathrm{t}_{1}\right)-09.01 .2020\left(\mathrm{t}_{2}\right)-16.02 .2020\left(\mathrm{t}_{3}\right)-15.03 .2020\left(\mathrm{t}_{4}\right)-09.12 .2019\left(\mathrm{t}_{1}\right)-09.01 .2020\left(\mathrm{t}_{2}\right)-16.02 .2020\left(\mathrm{t}_{3}\right)-15.03 .2020\left(\mathrm{t}_{4}\right)$ & $-09.12 .2019\left(\mathrm{t}_{1}\right)-09.01 .2020\left(\mathrm{t}_{2}\right)-16.02 .2020\left(\mathrm{t}_{3}\right)-15.03 .2020\left(\mathrm{t}_{4}\right)$ \\
\hline Net gain between $\mathrm{t}_{1}$ and $\mathrm{t}_{2}$ & Net gain between $\mathrm{t}_{2}$ and $\mathrm{t}_{3} \quad$ Net gain between $\mathrm{t}_{3}$ and $\mathrm{t}_{4} \quad$ Net loss between $\mathrm{t}_{3}$ and $\mathrm{t}_{4}$ &
\end{tabular}

Fig. 3. Day-to-day changes of the Airbnb occupancy ratio between December 2019 and March 2020. Source: Edited by the authors. 
The trend lines of London and New York show similar patterns here as well; the net loss in bookings appears at the beginning of April and the rate of relapse lower compared to Rome, where the most drastic decrease in occupancies was experienced. In Milan the magnitude of net loss is connected to the cancellation of the Design Week event. Copenhagen had net loss during almost the whole Period III, but the occupancy rate remained relatively high compared to the other investigated cities. Only two cities had no net loss in Period III: Sydney and Los Angeles. However, Sydney had two weeks at the beginning of April with only a minimal growth in occupancy rate. At the same time, the trend lines are quite similar for Los Angeles in each period. It confirms our previous findings; the effect of COVID-19 was minimal on the local Airbnb market during the analysed period. Tokyo shows the largest drop when comparing the maximum occupancies between data collections.

Compared to the peak occupancy of the holiday season, the maximum rates dropped more than 30 per cent for the next two phases. The possible explanations are two-fold; on the one hand, the drop is a "normal" process, since occupancy is usually higher during Christmas and New Year. On the other hand, China is one of the most important sources of tourists for Japan. In 2019 almost one-third of the tourists in Japan arrived from China. Losing one of the key sources of international tourism hit hard the Japanese Airbnb market as well. The number of new reservations in Cape Town also decreased significantly, but the length of net loss period is relatively short and new reservations were already made for May. This could be related to local circumstances: South Africa was where COVID-19 appeared the latest among the countries concerned.

During the third step of the analysis, the effects of coronavirus on different price categories of Airbnb were analysed. For the sake of that the daily average number of net gain/loss in each period for the price quartiles was calculated. Results show how the overall gain or loss occurred among the price quartiles (the first quartile consists of the most expensive listings, while the fourth the cheapest ones) during 2020 (Figure 4). Data for Beijing shows the cancellation of all previously booked listings since all bookings were suspended to Period III.

According to the reservation data, the Airbnb markets of all analysed cities were affected by the pandemic - but this effect showed different patterns. In Milan, Rome, Prague, Rio de Janeiro, Copenhagen all price categories had net loss. In the cases of Rome, Barcelona, Rio de Janeiro, London and New York the more expensive listings were more affected, however, it does not always mean net loss. Unlike the previous parts of the analysis, London and New York shows distinct differences here. While in the case of New York, there was a slight increase in all quartiles, in London a net loss was experienced above the median price. In Paris, Los Angeles, Copenhagen, Madrid, Prague and Milan the second and third quartiles suffered the largest decrease, while in Tokyo listings below the median price were the most affected. The rise of occupancy rate in Cape Town at the end of Period III was related to the cheapest price category. Due to the specific situation of Australia (i.e. wildfires) Sydney does not seem to fit into the above described categories.

\section{Discussion and conclusions}

The aim of this paper was to analyse the effects of COVID-19 on the Airbnb markets of different cities. To this end, the paper focused on three interrelated research questions. The first one referred to similarities and differences between various tourist locations regarding the effects of COVID-19. As data showed, COVID-19 pandemic had serious effects on the analysed local Airbnb markets, although the characteristics of the changes varied from city to city - thus, there is no uniform model of changes. Differences are determined by several factors, e.g.:

- the characteristics of local tourism markets (i.e. seasonality, price level, key source countries of tourists); 

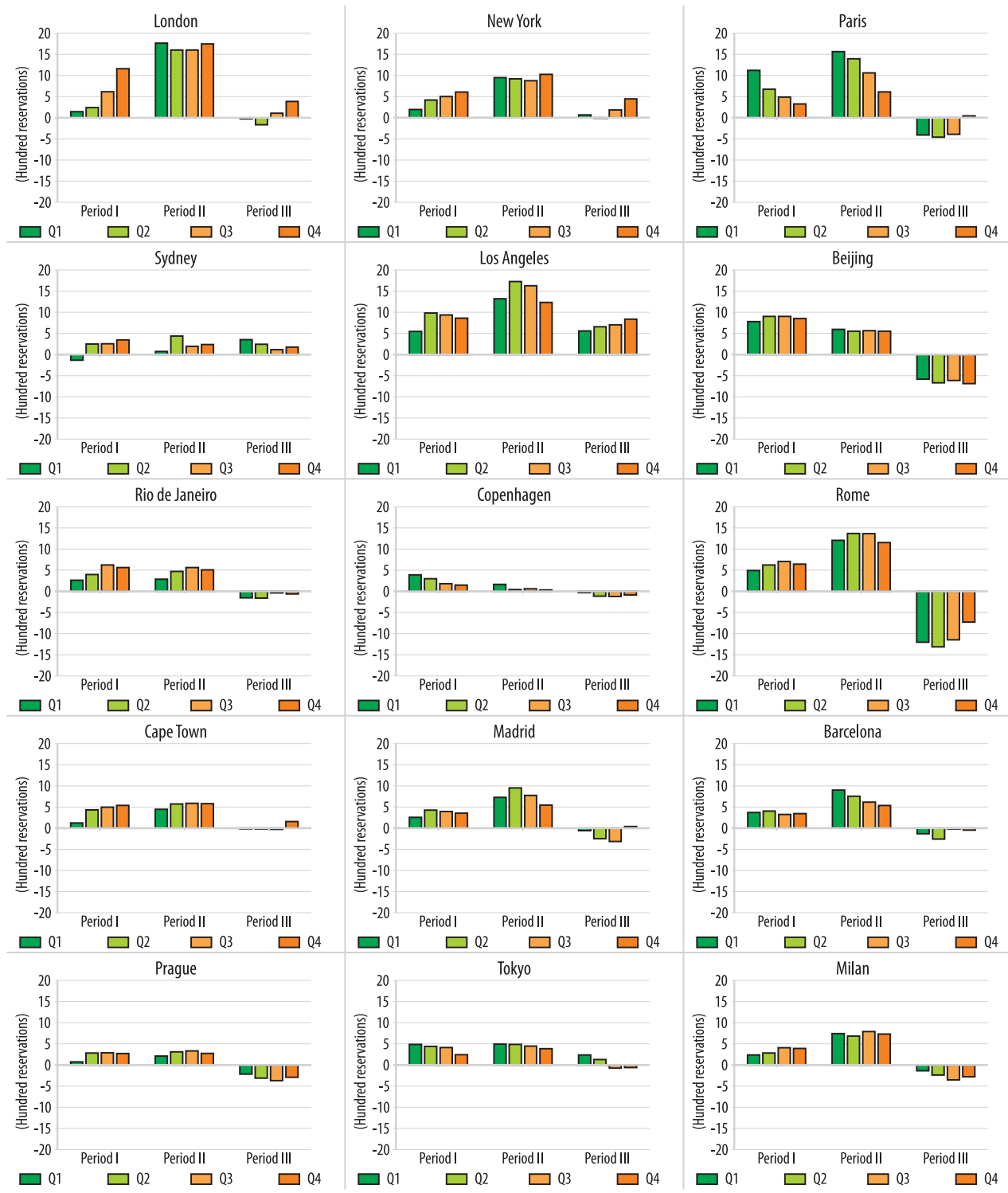

Fig. 4. Daily average reservations by quartiles between December 2019 and March 2020. Source: Edited by the authors.

- the time of the emergence of pandemic situation locally;

- government reactions and policies.

In some cases, the reservations made for a later date were not cancelled - as the case of Prague demonstrates. While its reasons are unknown due to the limitations of the analysed data, the relatively low infection ratio might have had an effect on this.

Based on our research findings it is difficult to provide comprehensive answers to the second and third research questions. The second 
question focused on the underlying factors of Airbnb cancellations. As the data showed, guests reacted to the pandemic quickly; they cancelled their reservations and did not make new ones - well before the travel restrictions. The declaration of global health emergency had little effect on booking trends. Instead, as the link between the change of occupancy rates and time of one case per million milestone shows, the local emergence of the disease contributed more to the perception of risk. To answer the third research question, it can be stated that the different price categories were affected differently - it was also related to the characteristics of local tourism markets. Thus, the local characteristics had significant role in shaping several aspects of booking trends.

The pandemic raises questions regarding the future of Airbnb - in a wider sense regarding the future of cities and tourism as well (Rubino, I. et al. 2020). According to several analyses, the pandemic can provide an opportunity for a transformation in tourism industry, moving towards a more sustainable future (Brouder, P. 2020; Gössling, S. et al. 2020; Hall, C.M. et al. 2020; Niewiadomski, P. 2020; SтANкоv, U. et al. 2020). Furthermore, as several studies highlighted (KE, Q. 2017; DolNiCAR, S. and ZARE, S. 2020), in many cases the hosts did not share their idle capacities instead, they managed multiple accommodations. These enterprise-like hosts can suffer significant losses during the crisis, they can go bankrupt or decide to leave the market or to decrease their portfolio (FARMAKI, A. et al. 2020). In addition, future policies can also affect the future of Airbnb. The effect of Airbnb on hotel industry and local communities was a highly debated issue in many localities. When the revival of tourism starts, local and national governments may support 'traditional' hotel companies due to their stronger lobbying power, role in employment and contribution to tax incomes. This support can be manifested in financial support or regulatory changes that would offer a significant advantage to hotels over P2P accommodations. This can lead to the decline of 'capitalist' multihosts (Dolnicar, S. and Zare, S. 2020).
The eventual shrinkage of local Airbnb offers would have effects on real estate and rental markets; the apartments withdrawn from the Airbnb market can become available for long-term rent or the owners can try to sell them. Thus, the price and the quantity of available flats (both for rent and for sale) can be affected by these changes. These processes can have a special relevance in post-socialist cities; where multi-hosts have a more prominent role compared to Western European cities. The regulation framework can be strengthened - as the attempts in Prague and Budapest demonstrate (Expats 2020; 24.hu 2020). If the regulations become stricter, it can change the tourism sector of these cities as well, e.g. by affecting the perceived value for money for tourists.

The length of the crisis and its effect on employment, incomes etc. will all influence how market processes and governmental policies evolve in the future. For example, tax breaks, stimulus packages and other governmental measures can provide help for certain actors in tourism and hospitality, influencing market processes (Dube, K. et al. 2020). Since the end of the pandemic and the subsequent economic crisis are not predictable (e.g. the consequences of the second wave of the disease OsкAм, J. 2020), it is too early to propose management recommendations. As the pandemic has caused an economic crisis, the recovery of tourism will take a longer time compared to the earlier disease-induced crises in tourism and hospitality. The experiences of previous pandemics (SARS-CoV and MERS-CoV in particular) provide insights into the possible effects and the possible directions of crisis relief. But COVID-19 caused distractions on an unprecedented scale - which means utilising past experiences has its limitations. Unlike in the case of previous diseases, the chance for a quick recovery of short-term rentals is extremely low because the length of the pandemic and the economic crisis.

Obviously, our study has certain limitations; it only focuses on certain cities and the timeframe of the analysis is limited too. We used publicly available data from Insideairbnb, 
which has its own limitations regarding the content, the scope and timeframe of the datasets. The analysis only shows the changes in booking trends; the perceptions and motivations beyond the decisions are unknown.

Future research could focus on the motivations of tourists, e.g. on why they cancel (or do not cancel) their bookings? Questions related to trust and perceived risks can provide further useful insights regarding the demand side of Airbnb. The markets trends on a longer term should also be analysed: questions of how long the decrease will be and how the structure of Airbnb supply will change. As we mentioned above, the policies towards Airbnb can also change - influencing P2P accommodation markets significantly. Thus, processes within various regulatory frameworks could also be compared. Last, but not least, the severity, the length and the effects of the second wave of the pandemic (and the related reactions of various actors) can vary from one location to another, causing unforeseeable processes. These should be also analysed in future researches.

Acknowledgement: This research was supported by the OTKA project K131534 (Transforming local housing markets in Hungarian big cities) financed by the National Research Development and Innovation Fund, Hungary.

\section{REFERENCES}

Adamiak, C. 2019. Current state and development of Airbnb accommodation offer in 167 countries. Current Issues in Tourism 1-19. Doi: 10.1080/13683500.2019.1696758

Aruan, D.T.H. and Felicia, F. 2019. Factors influencing travelers' behavioral intentions to use P2P accommodation based on trading activity: Airbnb vs Couchsurfing. International Journal of Culture, Tourism and Hospitality Research 13. (4): 487-504. Doi: 10.1108/IJCTHR-03-2019-0047

Baxter, E. and Bowen, D. 2004. Anatomy of tourism crisis: explaining the effects on tourism of the UK foot and mouth disease epidemics of 1967-68 and 2001 with special reference to media portrayal. International Journal of Tourism Research 6. (4): 263273. Doi: $10.1002 /$ jtr.487

Belotti, S. 2019. Sharing tourism as an opportunity for territorial regeneration: The case of Iseo Lake,
Italy. Hungarian Geographical Bulletin 68. (1): 79-92. Doi: 10.15201/hungeobull.68.1.6

Boros, L., Dudás, G., Kovalcsik, T., Papp, S. and Vida, G. 2018. Airbnb in Budapest: Analysing spatial patterns and room rates of hotels and peer-to-peer accommodations. Geojournal of Tourism and Geosites 21. (1): 26-38.

BRouder, P. 2020. Reset redux: possible evolutionary pathways towards the transformation of tourism in a COVID-19 world. Tourism Geographies 22. (3): 484-490. Doi: 10.1080/14616688.2020.1760928

Browne, A., St-Onge Ahmad, S., Beck, C.R. and NGUYEN-VAN-TAM, J.S. 2016. The roles of transportation and transportation hubs in the propagation of influenza and coronaviruses: a systematic review. Journal of Travel Medicine 23. (1): tav002. Doi: 10.1093/jtm/tav002

ÇAKAR, K. 2018. Critical success factors for tourist destination governance in times of crisis: a case study of Antalya, Turkey. Journal of Travel $\mathcal{E}$ Tourism Marketing 35. (6): 786-802. Doi: 10.1080/10548408.2017.1421495

Campiranon, K. and Scott, N. 2014. Critical Success Factors for Crisis Recovery Management: A Case Study of Phuket Hotels. Journal of Travel \& Tourism Marketing 31. (3): 313-326. Doi: 10.1080/10548408.2013.877414

Dann, D., Teubner, T. and Weinhardt, C. 2019. Poster child and guinea pig - insights from a structured literature review on Airbnb. International Journal of Contemporary Hospitality Management 31. (1): 427-473. Doi: 10.1108/IJCHM-03-2018-0186

Davis, X.M., Hay, K.A., Plier, D.A., Chaves, S.S., Lim, P.L., Caumes, E., Castelli, F., Kozarsky, P.E., Cetron, M.S. and Freedman, D.O. 2013. International Travelers as Sentinels for Sustained Influenza Transmission During the 2009 Influenza A(H1N1)pdm09 Pandemic. Journal of Travel Medicine 20. (3): 177-184. Doi: 10.1111/jtm.12025

Dogru, T., Hanks, L., Ozdemir, O., Kizildag, M., Ampountolas, A. and Demirer, I. 2020. Does Airbnb have a homogenous impact? Examining Airbnb's effect on hotels with different organizational structures. International Journal of Hospitality Management 86. 102451. Doi: 10.1016/j. ijhm.2020.102451

Dolnicar, S. and ZARE, S. 2020. COVID19 and Airbnb - Disrupting the Disruptor. Annals of Tourism Research 102961. Doi: 10.1016/j.annals.2020.102961

Dube, K., Nhamo, G. and Chiкodzi, D. 2020. COVID-19 cripples global restaurant and hospitality industry. Current Issues in Tourism 1-4. Doi: 10.1080/13683500.2020.1773416

Dudás, G., Vida, G., Kovalcsik, T. and Boros, L. 2017. A socio-economic analysis of Airbnb in New York City. Regional Statistics 7. (1): 135-151. Doi: 10.15196/RS07108

Edelman, B.G. and Geradin, D. 2015. Efficiencies and regulatory shortcuts: How should we regulate 
companies like Airbnb and Uber? SSRN Electronic Journal. Doi: 10.2139/ssrn.2658603

EnYedi, G. and KovÁcs, Z. 2006. Social Changes and Social Sustainability in Historical Urban Centres: the case of Central Europe. Pécs, Centre for Regional Studies of the Hungarian Academy of Sciences.

FANG, B., YE, Q. and LAW, R. 2016. Effect of sharing economy on tourism industry employment. Annals of Tourism Research 57. 264-267. Doi: 10.1016/j.annals.2015.11.018

Farmaki, A., Miguel, C., Drotarova, M.H., Aleksić, A., ČASNI, A.Č. and EfTHYMIADOU, F. 2020. Impacts of Covid-19 on peer-to-peer accommodation platforms: Host perceptions and responses. International Journal of Hospitality Management 91. 102663. Doi: 10.1016/j. ijhm.2020.102663

FAULKNER, B. 2001. Towards a framework for tourism disaster management. Tourism Management 22. (2): 135-147. Doi: 10.1016/S0261-5177(00)00048-0

Ferreri, M. and SANYAL, R. 2018. Platform economies and urban planning: Airbnb and regulated deregulation in London. Urban Studies 55. (15): 3353-3368. Doi: $10.1177 / 0042098017751982$

Findlater, A. and Bogoch, I.I. 2018. Human mobility and the global spread of infectious diseases: A focus on air travel. Trends in Parasitology 34. (9): 772-783. Doi: 10.1016/j.pt.2018.07.004

Fisher, J.J., Almanza, B.A., Behnke, C., Nelson, D.C. and NeAL, J. 2018. Norovirus on cruise ships: Motivation for handwashing? International Journal of Hospitality Management 75. 10-17. Doi: 10.1016/j. ijhm.2018.02.001

FöLDI, Zs. 2006. Neighbourhood Dynamics in InnerBudapest - a Realist Approach. Utrecht, Utrecht University.

Ginindza, S. and Tichanwa, T.M. 2019. The impact of sharing accommodation on the hotel occupancy rate in the kingdom of Swaziland. Current Issues in Tourism 22. (16): 1975-1991. Doi: 10.1080/13683500.2017.1408061

Gössling, S., Scott, D. and Hall, C.M. 2020. Pandemics, tourism and global change: a rapid assessment of COVID-19. Journal of Sustainable Tourism 1-20. Doi: 10.1080/09669582.2020.1758708

Grime, K., Kovács, Z. and Duke, V. 2019. The effects of privatisation in Central and Eastern Europe: Evidence from households in three Central European capitals. - In Transition, Cohesion and Regional Policy in Central and Eastern Europe. Eds.: Bachtler, J., Downes, R. and Gorzelak, G., London, Routledge, 51-68.

Gu, H. and WALL, G. 2006. Sars in China: Tourism impacts and market rejuvenation. Tourism Analysis 11. (6): 367-379. Doi: 10.3727/108354206781040731

GunTER, U. and ÖNDER, I. 2018. Determinants of Airbnb demand in Vienna and their implications for the traditional accommodation industry. Tourism Economics 24. (3): 270-293. Doi: 10.1177/1354816617731196
Gutiérrez, J., García-Palomares, J.C., Romanillos, G. and Salas-Olmedo, M.H. 2017. The eruption of Airbnb in tourist cities: Comparing spatial patterns of hotels and peer-to-peer accommodation in Barcelona. Tourism Management 62. 278-291. Doi: 10.1016/j.tourman.2017.05.003

Guttentag, D. 2015. Airbnb: disruptive innovation and the rise of an informal tourism accommodation sector. Current Issues in Tourism 18. (12): 1192-1217. Doi: 10.1080/13683500.2013.827159

Guttentag, D. 2017. Regulating innovation in the collaborative economy: An examination of Airbnb's early legal issues. - In Collaborative Economy and Tourism. Eds.: Dredge, D. and Gyimóthy, S., Cham, Switzerland, Springer, 97-128.

Guttentag, D. 2019. Progress on Airbnb: a literature review. Journal of Hospitality and Tourism Technology 10. (4): 814-844. Doi: 10.1108/JHTT-08-2018-0075

GYóDI, K. 2019. Airbnb in European cities: Business as usual or true sharing economy? Journal of Cleaner Production 221. 536-551. Doi: 10.1016/j. jclepro.2019.02.221

Hajibaba, H. and Dolnicar, S. 2017. Regulatory reactions around the world. - In Peer-to-Peer Accommodation Networks. Ed.: Dolnicar, S., Wolvercote, Oxford, Goodfellow Publishers, 120-136.

HaLL, C.M. 2010. Crisis events in tourism: subjects of crisis in tourism. Current Issues in Tourism 13. (5): 401-417. Doi: 10.1080/13683500.2010.491900

Hall, C.M., Scott, D. and Gössling, S. 2020. Pandemics, transformations and tourism: be careful what you wish for. Tourism Geographies 22. (3): 577-598. Doi: 10.1080/14616688.2020.1759131

Henderson, J.C. 2005. Responding to natural disasters: Managing a hotel in the aftermath of the Indian Ocean tsunami. Tourism and Hospitality Research 6. (1): 89-96. Doi: 10.1057/palgrave.thr.6040047

Henderson, J.C. and NG, A. 2004. Responding to crisis: severe acute respiratory syndrome (SARS) and hotels in Singapore. International Journal of Tourism Research 6. (6): 411-419. Doi: 10.1002/jtr.505

Higgins-Desbiolles, F. 2020. Socialising tourism for social and ecological justice after COVID-19. Tourism Geographies 22. (3). 610-623. Doi: 10.1080/14616688.2020.1757748

Ho, L.-L., Tsai, Y.-H., Lee, W.-P., Liao, S.-T., Wu, L.G. and WU, Y.-C. 2017. Taiwan's travel and border health measures in response to Zika. Health Security 15. (2): 185-191. Doi: 10.1089/hs.2016.0106

Hong Choi, K., Hyun Jung, J., Yeol Ryu, S., Do Kim, S. and Min Yoon, S. 2015. The relationship between Airbnb and the hotel revenue: In the case of Korea. Indian Journal of Science and Technology 8. (26). Doi: 10.17485/ijst/2015/v8i26/81013

Howes, M., Tangney, P., Reis, K., Grant-Smith, D., Heazle, M., Bosomworth, K. and Burton, P. 
2015. Towards networked governance: improving interagency communication and collaboration for disaster risk management and climate change adaptation in Australia. Journal of Environmental Planning and Management 58. (5): 757-776. Doi: 10.1080/09640568.2014.891974

Hu, M.R. and LeE, A.D. 2020. Airbnb, COVID-19 risk and lockdowns: Global evidence. SSRN Electronic Journal. Doi: 10.2139/ssrn.3589141

Huang, D., LiU, X., LAi, D. and Li, Z. 2019. Users and non-users of P2P accommodation. Journal of Hospitality and Tourism Technology 10. (3): 369-382. Doi: 10.1108/JHTT-06-2017-0037

Hugo, N. and Miller, H. 2017. Conflict resolution and recovery in Jamaica: the impact of the zika virus on destination image. Worldwide Hospitality and Tourism Themes 9. (5): 516-524. Doi: 10.1108/ WHATT-07-2017-0030

JAMAL, T. and BUDKE, C. 2020. Tourism in a world with pandemics: local-global responsibility and action. Journal of Tourism Futures (ahead-of-print). Doi: 10.1108/JTF-02-2020-0014

Jennings, L.C., Monto, A.S., Chan, P.K., Szucs, T.D. and Nicholson, K.G. 2008. Stockpiling prepandemic influenza vaccines: a new cornerstone of pandemic preparedness plans. The Lancet Infectious Diseases 8. (10): 650-658. Doi: 10.1016/S1473-3099(08)70232-9

JiANG, Y. and RITchie, B.W. 2017. Disaster collaboration in tourism: Motives, impediments and success factors. Journal of Hospitality and Tourism Management 31. 70-82. Doi: 10.1016/j.jhtm.2016.09.004

Joo, H., Maskery, B.A., Berro, A.D., Rotz, L.D., Lee, Y.-K. and Brown, C.M. 2019. Economic impact of the 2015 MERS outbreak on the Republic of Korea's tourism-related industries. Health Security 17. (2): 100-108. Doi: 10.1089/hs.2018.0115

Kamel Boulos, M.N. and Geraghty, E.M. 2020. Geographical tracking and mapping of coronavirus disease COVID-19/severe acute respiratory syndrome coronavirus 2 (SARS-CoV-2) epidemic and associated events around the world: How $21^{\text {st }}$ century GIS technologies are supporting the global fight against outbr. International Journal of Health Geographics 19. (1): 1-8. Doi: 10.1186/s12942020-00202-8

KE, Q. 2017. Sharing means renting? An entiremarketplace analysis of Airbnb. WebSci '17: Proceedings of the 2017 ACM on Web Science Conference. New York, Association for Computing Machinery, 131-139. Available at https://doi. org/10.1145/3091478.3091504

KIM, J., KIM, J., LeE, S.K. and TANG, L.R. 2020. Effects of epidemic disease outbreaks on financial performance of restaurants: Event study method approach. Journal of Hospitality and Tourism Management 43. 32-41. Doi: 10.1016/j. jhtm.2020.01.015
KuJučnikov, A., KrajČíK, V. and Vincúrová, Z. 2018. International sharing economy: The case of airbnb in the Czech Republic. Economics and Sociology 11. (2): 126-137. Doi: 10.14254/2071-789X.2018/11-2/9

Korcelli-Olejniczak, E. and Tammaru, T. 2020. Social diversity and social interaction: Community integration and disintegration in inner-city. Mitteilungen der Österreichischen Geographischen Gesellschaft 1. 91-115. Doi: 10.1553/moegg161s91

Kouřil, P. and Ferenčuhová, S. 2020. "Smart" quarantine and "blanket" quarantine: the Czech response to the COVID-19 pandemic. Eurasian Geography and Economics 6. (21): 1-11. Doi: 10.1080/15387216.2020.1783338

KovÁcs, Z. 2020. Do market forces reduce segregation? The controversies of post-socialist urban regions of Central and Eastern Europe. - In Handbook of Urban Segregation. Ed.: Musterd, S., Cheltenham, Edward Elgar Publishing, 118-133.

Kuo, H.-I., Chang, C.-L., Huang, B.-W., Chen, C.-C. and McAleer, M. 2009. Estimating the impact of avian flu on international tourism demand using panel data. Tourism Economics 15. (3): 501-511. Doi 10.5367/000000009789036611

LAw, R. 2006. The perceived impact of risks on travel decisions. International Journal of Tourism Research 8. (4): 289-300. Doi: 10.1002/jtr.576

LEAN, H. and SMYTH, R. 2009. Asian financial crisis, avian flu and terrorist threats: Are shocks to Malaysian tourist arrivals permanent or transitory? Asia Pacific Journal of Tourism Research 14. (3): 301-321.

Lee, C.-K., Song, H.-J., Bendle, L.J., Kim, M.-J. and HAN, H. 2012. The impact of non-pharmaceutical interventions for 2009 H1N1 influenza on travel intentions: A model of goal-directed behavior. Tourism Management 33. (1): 89-99. Doi: 10.1016/j. tourman.2011.02.006

Lim, J. and Won, D. 2020. How Las Vegas' tourism could survive an economic crisis? Cities 100. 102643. Doi: 10.1016/j.cities.2020.102643

Mahadevan, R. 2018. Examination of motivations and attitudes of peer-to-peer users in the accommodation sharing economy. Journal of Hospitality Marketing \& Management 27. (6): 679-692. Doi: 10.1080/19368623.2018.1431994

MAO, C.-K., Ding, C.G. and LeE, H.-Y. 2010. Post-SARS tourist arrival recovery patterns: An analysis based on a catastrophe theory. Tourism Management 31 (6): 855-861. Doi: 10.1016/j.tourman.2009.09.003

MaO, Z.E., Jones, M.F., LI, M., WeI, W. and LyU, J. 2020. Sleeping in a stranger's home: A trust formation model for Airbnb. Journal of Hospitality and Tourism Management 42. 67-76. Doi: 10.1016/j. jhtm.2019.11.012

Mao, Z. and Lyu, J. 2017. Why travelers use Airbnb again? International Journal of Contemporary Hospitality Management 29. (9): 2464-2482. Doi: 10.1108/IJCHM-08-2016-0439 
Maphanga, P.M. and Henama, U.S. 2019. The tourism impact of Ebola in Africa: Lessons on crisis management. African Journal of Hospitality, Tourism and Leisure 8. (3): 1-13.

McAleer, M., Huang, B.-W., Kuo, H.-I., Chen, C.-C. and CHANG, C.-L. 2010. An econometric analysis of SARS and Avian Flu on international tourist arrivals to Asia. Environmental Modelling \& Software 25. (1): 100-106. Doi: 10.1016/j.envsoft.2009.07.015

Monterrubio, J.C. 2010. Short-term economic impacts of influenza A (H1N1) and government reaction on the Mexican tourism industry: an analysis of the media. International Journal of Tourism Policy 3. (1): 1-13. Doi: 10.1504/IJTP.2010.031599

Nelson, E.J., Luetke, M.C., McKinney, C. and Omodior, O. 2019. Knowledge of the sexual transmission of Zika virus and preventive practices against Zika virus among U.S. travelers. Journal of Community Health 44. (2): 377-386. Doi: 10.1007/ s10900-018-0594-X

Niewiadomski, P. 2020. COVID-19: from temporary de-globalisation to a re-discovery of tourism? Tourism Geographies 22. (3): 641-652. Doi: 10.1080/14616688.2020.1757749

Novelli, M., Gussing Burgess, L., Jones, A. and Ritchie, B.W. 2018. 'No Ebola...still doomed' - The Ebola-induced tourism crisis. Annals of Tourism Research 70. 76-87. Doi: 10.1016/j.annals.2018.03.006

Omrani, A.S. and Shalhoub, S. 2015. Middle East respiratory syndrome coronavirus (MERSCoV): what lessons can we learn? Journal of Hospital Infection 91. (3): 188-196. Doi: 10.1016/j. jhin.2015.08.002

Osкam, J. 2020. Assumptions, plans and actual responses. The uncharted territory of the Covid-19 pandemic. HTH Discussion Paper May 2020, The Hague, Hospitality Research Centre. Available at https:// doi.org/10.13140/RG.2.2.36157.08169

Отоо, F.E. and KIм, S.S. 2018. Is there stability underneath health risk resilience in Hong Kong inbound tourism? Asia Pacific Journal of Tourism Research 23. (4): 344-358. Doi: 10.1080/10941665.2018.1433700

PAge, S., Song, H. and Wu, D.C. 2012. Assessing the impacts of the global economic crisis and swine flu on inbound tourism demand in the United Kingdom. Journal of Travel Research 51. (2): 142-153. Doi: 10.1177/0047287511400754

Pung, J.M., Del Chiappa, G. and Sini, L. 2019. Booking experiences on sharing economy platforms: an exploration of tourists' motivations and constraints. Current Issues in Tourism 1-13. Doi: 10.1080/13683500.2019.1690434

Rassy, D. and SмiтH, R.D. 2013. The economic impact of H1N1 on Mexico's tourist and pork sectors. Health Economics 22. (7): 824-834. Doi: 10.1002/ hec. 2862

Rátz, T., Michalkó, G. and Keszeg, R. 2020. Educational tourism and nation building: Cross- border school trips in the Carpathian basin. Hungarian Geographical Bulletin 69. (1): 57-71. Doi: 10.15201/hungeobull.69.1.5

Reddy, M.V., Boyd, S.W. and Nica, M. 2020. Towards a post-conflict tourism recovery framework. Annals of Tourism Research 84. 102940. Doi: 10.1016/j.annals.2020.102940

Reisinger, Y. and Mavondo, F. 2005. Travel anxiety and intentions to travel internationally: implications of travel risk perception. Journal of Travel Research 43. (3): 212-225. Doi: 10.1177/0047287504272017

Ren, X. 2020. Pandemic and lockdown: a territorial approach to COVID-19 in China, Italy and the United States. Eurasian Geography and Economics 1-12. Doi: 10.1080/15387216.2020.1762103

Rivera, M.A. 2020. Hitting the reset button for hospitality research in times of crisis: Covid19 and beyond. International Journal of Hospitality Management 87. 102528. Doi: 10.1016/j.ijhm.2020.102528

Robertson, D., Oliver, C. and Nost, E. 2020. Short-term rentals as digitally-mediated tourism gentrification: impacts on housing in New Orleans. Tourism Geographies 22. (5): 675-686. Doi: 10.1080/14616688.2020.1765011

Rubino, I., Coscia, C. and Curto, R. 2020. Identifying spatial relationships between built heritage resources and short-term rentals before the Covid-19 pandemic: Exploratory perspectives on sustainability issues. Sustainability 12. (11): 4533. Doi: 10.3390/su12114533

Ryu, S., GaO, H., Wong, J.Y., Shiu, E.Y.C., XIAo, J., Fong, M.W. and Cowling, B.J. 2020. Non-pharmaceutical measures for pandemic influenza in non-healthcare settings -International travel-related measures. Emerging Infectious Diseases 26. (5): 961-966. Doi: 10.3201/eid2605.190993

Semenza, J.C. and Ebi, K.L. 2019. Climate change impact on migration, travel, travel destinations and the tourism industry. Journal of Travel Medicine 26. (5): Doi: 10.1093/jtm/taz026

Sharpley, R. and Craven, B. 2001. The 2001 foot and mouth crisis - Rural economy and tourism policy implications: A comment. Current Issues in Tourism 4. (6): 527-537. Doi: 10.1080/13683500108667901

SHI, W. and LI, K.X. 2017. Impact of unexpected events on inbound tourism demand modelling: evidence of Middle East Respiratory Syndrome outbreak in South Korea. Asia Pacific Journal of Tourism Research 22. (3): 344-356. Doi: 10.1080/10941665.2016.1250795

Smith, M.K., Egedy, T., Csizmady, A., JancsiK, A., Olt, G. and Michalkó, G. 2018. Non-planning and tourism consumption in Budapest's inner city. Tourism Geographies 20. (3): 524-548. Doi: 10.1080/14616688.2017.1387809

Smith, M., Sulyok, J., Jancsik, A., Puczkó, L., Kiss, K., Sziva, I., Papp-VÁry, Á.F. and Michalkó, G. 2018. Nomen est omen - Tourist image of the Balkans. Hungarian Geographical Bulletin 67. (2): 173-188. Doi: 10.15201/hungeobull.67.2.5 
So, K.K.F., OH, H. and Min, S. 2018. Motivations and constraints of Airbnb consumers: Findings from a mixed-methods approach. Tourism Management 67. 224-236. Doi: 10.1016/j.tourman.2018.01.009

Sparke, M. and Anguelov, D. 2012. H1N1, globalization and the epidemiology of inequality. Health \& Place 18. (4): 726-736. Doi: 10.1016/j. healthplace.2011.09.001

Stankov, U., Filimonau, V. and Vujičić, M.D. 2020. A mindful shift: an opportunity for mindfulness-driven tourism in a post-pandemic world. Tourism Geographies 22. (3): 703-712. Doi: 10.1080/14616688.2020.1768432

Stergiou, D.P. and Farmaki, A. 2019. Resident perceptions of the impacts of P2P accommodation: Implications for neighbourhoods. International Journal of Hospitality Management 102411. Doi: 10.1016/j.ijhm.2019.102411

STrielkowski, W. 2020. International tourism and COVID-19: Recovery strategies for tourism organisations. Preprints. Doi: https://doi. org/10.20944/preprints202003.0445.v1

SÝkorA, L. and Bouzarovski, S. 2012. Multiple Transformations. Urban Studies 49. (1): 43-60. Doi: 10.1177/0042098010397402

TANG, C.F. and TAN, E.C. 2016. The determinants of inbound tourism demand in Malaysia: another visit with non-stationary panel data approach. Anatolia 27. (2): 189-200. Doi: 10.1080/13032917.2015.1084345

Tran, T.H. and Filimonau, V. 2020. The (de) motivation factors in choosing Airbnb amongst Vietnamese consumers. Journal of Hospitality and Tourism Management 42. 130-140. Doi: 10.1016/j.jhtm.2019.10.011

Vinogradov, E., Leick, B. and Kivedal, B.K. 2020. An agent-based modelling approach to housing market regulations and Airbnb-induced tourism. Tourism Management 77. 104004. Doi: 10.1016/j.tourman.2019.104004

Wachsmuth, D. and Weisler, A. 2018. Airbnb and the rent gap: Gentrification through the sharing economy. Environment and Planning A: Economy and Space 50. (6): 1147-1170. Doi: 10.1177/0308518X18778038

Widmar, N.J.O., Dominick, S.R., Ruple, A. and TyNER, W.E. 2017. The influence of health concern on travel plans with focus on the Zika virus in 2016. Preventive Medicine Reports 6. 162-170. Doi: 10.1016/j.pmedr.2017.02.023

Wilson, M.E. and Chen, L.H. 2020. Travellers give wings to novel coronavirus (2019-nCoV). Journal of Travel Medicine 27. (2): Doi: 10.1093/ jtm/taaa015

Wu, E.H.C., LAw, R. and JiAng, B. 2010. The impact of infectious diseases on hotel occu- pancy rate based on independent component analysis. International Journal of Hospitality Management 29. (4): 751-753. Doi: 10.1016/j. ijhm.2009.07.001

YI, J., YUAN, G. and Yoo, C. 2020. The effect of the perceived risk on the adoption of the sharing economy in the tourism industry: The case of Airbnb. Information Processing $\mathcal{E}$ Management 57. (1): 102108. Doi: 10.1016/j.ipm.2019.102108

Zervas, G., Proserpio, D. and Byers, J.W. 2017. The rise of the sharing economy: Estimating the impact of Airbnb on the hotel industry. Journal of Marketing Research 54. (5): 687-705. Doi: 10.1509/jmr.15.0204

Zheng, Y., GoH, E. and WeN, J. 2020. The effects of misleading media reports about COVID-19 on Chinese tourists' mental health: a perspective article. Anatolia 31. (2): 337-340. Doi: 10.1080/13032917.2020.1747208

Other sources:

24.hu 2020. Both the Hungarian government and the Budapest would regulate short-term rentals, the downtown real estate market could be transformed. Available at https://24.hu/belfold/2020/07/03/airbnb-lakasbudapest-tiltas-turizmus/

Champer Champ 2020. Chinese tourism in Australia Statistics. Available at https://camperchamp.com. au/statistics/australia/chinese-visitors/

Expats 2020. Prague City Hall wants Parliament to allow stricter regulation of Airbnb. Available at https:// news.expats.cz/accommodation-in-the-czechrepublic/prague-city-hall-wants-parliament-toallow-stricter-regulation-of-airbnb/

Insideairbnb 2020. Get the data. Available at http:// insideairbnb.com/get-the-data.html

Reuters 2020. Airbnb extends booking suspension in Beijing to May. Available at https://www.reuters. com/article/us-china-health-airbnb/airbnb-extendsbooking- suspension-in-beijing-to-may-idUSKBN2060NT

UNWTO 2020. Message from Madrid: Tourism and Covid-19. Available at https://www.unwto.org/ news/madrid-tourism-covid-19

WHO 2020: WHO Director-General's opening remarks at the media briefing on COVID-19 - 11 March 2020 Available at https://www.who.int/dg/speeches/ detail/who- director-general-s-opening-remarksat-the-media-briefing-on-covid-19-11-march-2020

Worldometer 2020. COVID-19 Coronavirus Pandemic. Available at https://www.worldometers.info/ coronavirus/ 
